\title{
The analysis of the relation of education investment and urban-rural income gap in YUNNAN Province
}

\author{
FEILIANG NIU \\ Economics Dept. \\ Yunnan University \\ Kunming, China \\ e-mail: niufeiliang@aliyun.com
}

\author{
QINGHUA HUANG \\ Management and Economics Dept. \\ Kunming University of Science and Technology \\ Kunming, China \\ e-mail:nflhua@sina.com
}

\begin{abstract}
Education is a typical process of accumulating human capital, which not only improves the overall quality of rural labor, but also increases income. The income gap between urban and rural residents is closely associated with education investment in Yunnan Province. Through the use of econometric model, the research finds that investment in both education and fixed assets can lead to the widening of urban-rural income gap. Therefore, measures should be taken to ensure equal allocation of financial resources to narrow the income gap caused by education investment and other factors.
\end{abstract}

Keywords-education investment; urban-rural income gap;causality

\section{INTRODUCTION}

Education is a typical process of accumulating human capital[1]. It not only improves the overall quality of rural labor, helping them adopt advanced technology in agricultural and non-agricultural production, but also provides a vast of rural labor with various opportunities in ongoing urbanization and industrialization to help them seek their own development path[2]. In recent years, China's rural education improves obviously, but there still exist many problems[3]. Compared with urban education, rural education remains at an absolute disadvantage; rural education expenditure is far behind that of urban areas; the average years of education of rural population are less than that of urban population and the gap is even larger in high-level education. Urban-rural education gap is an important reason of widening urban-rural income gap which is a cruel reality.[4] Education originally is one of the important methods of narrowing gap, but the reality is that urban-rural education gap is increasingly widening. The unequal education resources and education conditions enjoyed by urban and rural population will directly lead to the widening of gap in their knowledge structure, economic status and income in the future. An analysis shows that education opportunities enjoyed by urban and rural labor are unequal because of the constraints of government's public expenditure and household income level. It directly leads to the differences of labor's level of education and further quality between urban and rural areas. The differences affect labor's productivity and are eventually reflected on income disparity[5].

\section{URBAN-RURAL INCOME GAP IN YUNNAN PROVINCE}

The weighted coefficient of variation is used to measure income gap among different regions. $p_{j}$ represents the population of region $\mathrm{j}$ and $\mathrm{p}$ is the total number of population. If the weighted coefficient of variation is bigger, the difference of regional economic development is larger; on the contrary, if the coefficient is smaller, the difference is smaller. The weighted coefficient of variation is suited to measure the relevant income gap with consideration of regional economic gross or the size of population. However, its calculation is complex. As with the variation coefficient, the weighted coefficient of variation measures the average income level of regions and Yunnan Province, without considering the difference among the scope of Yunnan Province or the disparity among different regions. Theoretically, if the average income level of each region tends to be the same, the value of variation coefficient or weighted coefficient of variation will be smaller. But in reality, the change of regional difference is likely to become larger. The paper takes per capita income of each prefecture or city as analyzed variable to calculate the variation coefficient of 16 prefectures or cities that is used to compare discrete level of income of each prefecture or city. Through research, it is found that the income gap between prefectures or cities in Yunnan Province is narrowing and the variation coefficient gradually reduces from 0.4528 in 2001 to 0.3635 in 2010 . 
TABLE I.

VARIATION COEFFICIENT OF URBAN-RURALINCOME GAP IN YUNNAN PROVINCE

\begin{tabular}{lccccc}
\hline \multicolumn{1}{c}{ TIME } & $\mathbf{2 0 0 1}$ & $\mathbf{2 0 0 2}$ & $\mathbf{2 0 0 3}$ & $\mathbf{2 0 0 4}$ & $\mathbf{2 0 0 5}$ \\
\hline standard deviation & 458303.3 & 472969.07 & 495181.34 & 621323.08 & 759266.94 \\
average & 1495.08 & 1536.24 & 1608.29 & 1770.66 & 1960.22 \\
variation coefficient & 0.4528 & 0.4477 & 0.4375 & 0.4451 & 0.4445 \\
\hline \multicolumn{7}{c}{ TIME } & $\mathbf{2 0 0 6}$ & $\mathbf{2 0 0 7}$ & $\mathbf{2 0 0 8}$ & $\mathbf{2 0 0 9}$ & $\mathbf{2 0 1 0}$ \\
\hline standard deviation & 849631.4 & 1038413.41 & 1326147.55 & 1524123.3 & 1892899.06 \\
average & 2135.88 & 2478.38 & 2904.61 & 3305.61 & 3784.54 \\
variation coefficient & 0.4316 & 0.4112 & 0.3965 & 0.3735 & 0.3635 \\
\hline
\end{tabular}

Data sources: adapted from data of Statistical Almanac of Yunnan Province(2002-2011)

\section{Theoretical Model CONSTRuction AND QuantiTATIVE}

\section{ANALYSIS}

1) According to human capital theory, econometric model is constructed to analyze the influence of education on urban-rural income gap. Model construction: $\mathrm{GAP}_{u r}=\alpha+\beta_{0} \mathrm{e} d u_{\mathrm{exp}}+\beta_{1} f i x+\beta_{2} e d u_{\mathrm{exp}} \times f i x+\varepsilon_{t}$

2) GAP $_{u r}$ represents urban-rural income gap, measured by the ratio of per capita disposable income of urban residents to per capita net income of rural residents. $\mathrm{GAP}_{u r}$ represents per capita education expenditure investment; $f i x$ is fixed assets investment; the two items are measured by the ratio of financial expenditure on certain aspect to that year's GDP. ${ }^{\varepsilon_{t}}$ is random disturbance term. If estimated coefficients of $e d u_{\exp }$ and $f i x$ are negative, it indicates that the two items are conducive to narrow urban-rural income gap. On the one hand, the interaction item of per capita education expenditure investment and per capita fixed assets investment inspects their relation; on the other hand, it can be used to analyze effect of fixed assets investment on income gap through its effect on human capital level. If estimated coefficient is obviously a positive number, it shows that marginal utility of a variable increases as that of another variable increases.

3) The dataset adopted in the paper is from relevant social and economic data of statistical almanac of Yunnan Province and China from 2001 to 2010, in which fixed assets investment is "fix", total education investment is "edu", urban-rural income gap is "gap", meaning urban-rural disposable income balance. 


\begin{tabular}{llll}
\multicolumn{2}{l}{ time urban per capita disposable income rural per capita disposable income total education investment (10,000) fixed assets (10,000) } \\
\hline 20016859.60 & 2366.40 & 109655.20 & 37213.49 \\
20027702.80 & 2475.60 & 120332.70 & 43499.91 \\
20038472.20 & 2622.20 & 135822.80 & 55566.61 \\
20049421.60 & 2936.40 & 159878.30 & 70477.40 \\
200510493.00 & 3254.90 & 184937.40 & 88773.62 \\
200611759.50 & 3587.00 & 216314.40 & 109998.2 \\
200713785.80 & 4140.40 & 265810.30 & 137323.94 \\
200815780.80 & 4760.60 & 314045.40 & 172828.4 \\
200917174.70 & 5153.20 & 340902.80 & 224598.77 \\
201019109.40 & 5919.00 & 401512.80 & 251683.77 \\
\hline
\end{tabular}

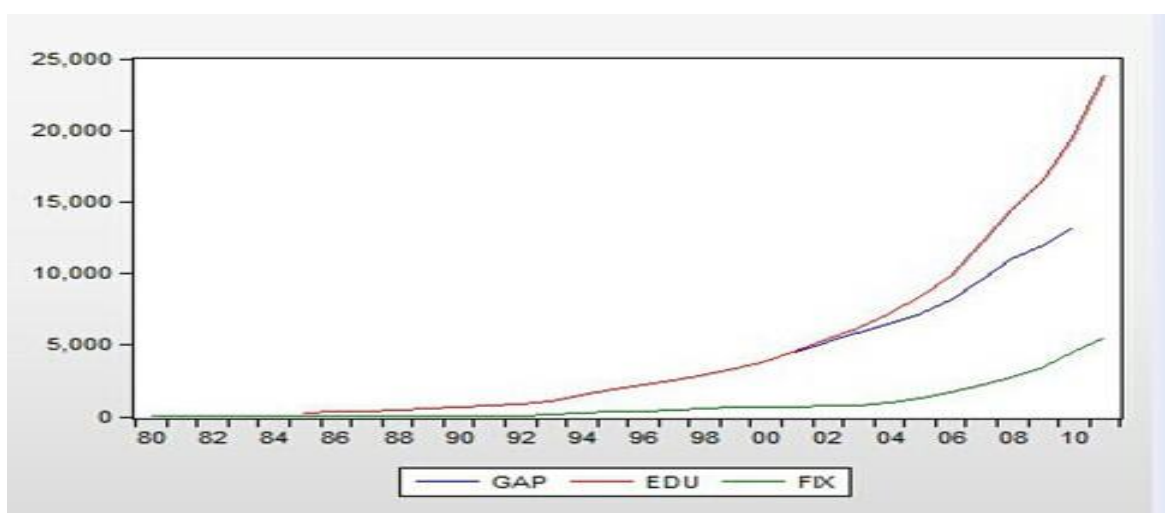

Fig. 1. Measurement simulation

$\mathrm{GAPt}=4647.207+-22.30308 \mathrm{EDUt}+4.085263 \mathrm{FIXt}+\varepsilon \mathrm{t}$

The model indicates that the increment of education investment will narrow income gap, but the increment of fixed assets investment will widen income gap.

\section{SugGestion AND Policies}

Education investment and income gap appear in a negative correlation, so the proportion of education expenditure in government expenditure should be raised, especially the proportion of rural education expenditure investment. On the basis of increasing total investment of education expenditure, the growth rate of rural education expenditure investment should be raised and the gap of education expenditure investment between urban and rural areas should be narrowed, especially in the stage of compulsory education.

The relativity about fixed assets investment and income gap is negative, because fixed assets flowing into rural and urban areas are uneven. Thus, fixed assets investment in rural areas should be increased; the gap of fixed assets investment between urban and rural areas should be narrowed; rural infrastructure, particularly the infrastructure driving economic growth such as road, should be developed; rural investment environment should be improved; the government can make use of tax and other preferential policies to attract capital flowing into rural areas and develop enterprises of townships; we should give play to the advantage of low pay for rural human capital to promote the employment of rural population, make full use of rural human capital, improve rural employment environment and raise rural income.

We should build systematically investment laws and policies of higher education in order to achieve higher education funds investment amount and get a moderate growth, as while as to mobilize government, enterprises pay more attention to the enthusiasm of the education, even their family investing in higher education also. Higher education must build security investment policy which can support by law. On 
the basis of the existing "education law", "higher education act", our country should enhance and promote the relevant laws and regulations of higher education for the investment. Government, enterprises and educates, even with and their families in the higher education investment enjoying the preferential fiscal and taxation policy etc, as to create a good atmosphere for investment in higher education, and to ensure the steady growth of higher education investment. Allowing higher education bonds being built when conditions are ready, and we could alleviate the government and social investment together.

After China entering the WTO, education ,especially higher education has been opening to the outside world as a service project. Efforts to develop international education market, is not only the inevitable demand for international higher education market competition, we also actively deal with after joining the WTO effective measures for the internationalization of higher education. With the advancement of construction of the china-ASEAN free trade area, Yunnan province's regional advantage in international education market is becoming bright. Therefore, to make full use of the advantages of geographic location in Yunnan province, drawing lessons from foreign successful experience, the internationalization of higher education would give students the potential to make systematically innovation, while we can develop the international education market as an innovation of higher education investment system, increasing the higher education market, as while as increasing the important means and measures in higher education investment To encourage universities to advance the internationalization of Yunnan as an ascending important way of running school, and make full use of Yunnan and South Asia countries' adjacent favorable geographical conditions, and to invest in southeast Asia, South Asia, the construction of China facing southeast Asia and South Asia base for teaching Chinese as a foreign language and personnel training, we should train a large number of Chinese application-oriented talents, senior management talents and required talents of the china-ASEAN free trade area. In Yunnan province, the government should, in a planned way, construct a batch of high level international talent training base and set up series policies about the surrounding countries, including economy, culture, education and other scientific research institutes. It also needs to strive to building Yunnan into a place which has great influence in China and southeast Asia, South Asia about international talent training and research base.

\section{ACKNOWLEDGEMENT}

The paper is funded by Education scientific planning fund of Yunnan Province "the research of the influence of residential education investment on urban-rural income gap in Yunnan Province" (NO.Y13002), Key projects in 2013 teaching education reform project (comprehensive) of Yunnan university(No.2013 zz7 )and The fourth batch of young and middle-aged backbone teachers training plan of Yunnan university, (No.XT412003).

\section{REFERENCES}

[1] Stiglitz,J.E. 1975. "The theory of "screening", education and the distribution of income". American Economic Review, 65, 283-300

[2] Psacharopoulos, G.1994. Returns to education: A further international update and implications. J. World Development,22(9): 1325-1343.

[3] Wang Xiaolu, Fan Gang.2005. "Analysis of the trend and factors of China's income gap". J. Economy Research, 2005 (10) : 24-36

[4] Liu Yulin, Chen Ling. 2012. "Joint effects of investment and social security on urban-rural income gap ".J. Demography, 2012(2):10-18

[5] Chen Binkai, Zhang Pengfei, Yang Rudai. 2010. "Education investment of the government, human capital investment and urban-rural income gap of China ".J. Management World, 2010(1). 